Article

\title{
Analytical Methodology for Trace Determination of Propoxur and Fenitrothion Pesticide Residues by Decanoic Acid Modified Magnetic Nanoparticles
}

\author{
Amine Gizem Canlı ${ }^{1}$, Bilge Sürücü ${ }^{1}$, Halil İbrahim Ulusoy ${ }^{1, * \mathbb{D}}$, Erkan Yılmaz ${ }^{2,3}$, \\ Abuzar Kabir 4 (D) and Marcello Locatelli ${ }^{5, *(D)}$ \\ 1 Department of Analytical Chemistry, Faculty of Pharmacy, Cumhuriyet University, 58140 Sivas, Turkey; \\ eczaminegizem@gmail.com (A.G.C.); bilgesurucu@hotmail.com (B.S.) \\ 2 Department of Analytical Chemistry, Faculty of Pharmacy, Erciyes University, 38039 Kayseri, Turkey; \\ erkanyilmaz@erciyes.edu.tr \\ 3 ERNAM-Erciyes University Nanotechnology Application and Research Center, 38039 Kayseri, Turkey \\ 4 Department of Chemistry and Biochemistry, International Forensic Research Institute, Florida International \\ University, 11200 SW 8th St, Miami, FL 33199, USA; akabir@fiu.edu \\ 5 Department of Pharmacy, University of Chieti-Pescara “G. d'Annunzio", Via dei Vestini 31, 66100 Chieti, \\ Italy \\ * Correspondence: hiulusoy@yahoo.com (H.İ.U.); m.locatelli@unich.it (M.L.); Tel.: +39-0871-3554-590 (M.L.); \\ Fax: +90-346-219-10-10 (H.I.U.)
}

Academic Editor: Rafael Lucena

Received: 2 November 2019; Accepted: 13 December 2019; Published: 17 December 2019

\begin{abstract}
A sensitive, rapid, reliable, and easily applicable method based on magnetic solid phase extraction (MSPE) combined with HPLC-PDA was developed for monitoring propoxur (PRO) and fenitrothion (FEN) pesticides in environmental water samples. The effect of major experimental variables on the extraction efficiency of both the pesticides was investigated and optimized systematically. For this purpose, a new magnetic material containing decanoic acid on the surface of particles was synthesized and characterized by XRD, FT-IR, SEM, EDX, and TGA analysis in detail. The simultaneous determination of pesticide molecules was carried out by using a Luna Omega C18 column, isocratic elution of acetonitrile (ACN): Water $(70: 30 v / v)$ with a flow rate of $1.2 \mathrm{~mL}$ $\mathrm{min}^{-1}$. After MSPE, the linear range for pesticide molecules $\left(\mathrm{r}^{2}>0.9982\right)$ was obtained in the range of 5-800 and 10-800 $\mathrm{ng} \mathrm{mL}^{-1}$, respectively. The limit of detections (LOD) are 1.43 and $4.71 \mathrm{ng} \mathrm{mL}^{-1}$ for PRO and FEN, respectively while RSDs \% are below $3.5 \%$. The applicability of the proposed method in four different environmental samples were also investigated using a standard addition-recovery procedure. Average recoveries at two spiking levels were over the range of $91.3-102.5 \%$ with RSD $<5.0 \%(n=3)$. The obtained results show that decanoic acid grafted magnetic particles in MSPE combined with HPLC-PDA is a fast and simple method for the determination of PRO and FEN in environmental water samples.
\end{abstract}

Keywords: fenitrothion; propoxur; HPLC; magnetic solid phase extraction; environmental water samples

\section{Introduction}

Pesticides are used to increase productivity in agriculture and avoid various insects in residential and other public areas. They can remain on food during the process of growing, collecting, distributing, and consuming vegetables and fruits. Moreover, their residues can exist in the air, water, and soil as the result of transferring these molecules. The pesticides have many adverse effects on humans, 
environment, and other organisms in the ecosystem. Therefore, analysis of pesticides residues in food and environmental samples is an important challenge and closely monitored by most of the legal agencies in Europe and other developed countries. Therefore, identification and determination of pesticide residues is very critical for the human health and wellbeing, as well as for the ecosystem. When pesticides are applied to an area, some of their molecules evaporate and pass to living things through respiration and the other part condenses on the surface of the soil such as snow, rain, and irrigation water. Then, these substances are consumed by plants or water and accumulate in fat tissues [1].

As an organic compound, organophosphorus and carbamate pesticides are extensively applied to agricultural areas owing to their great effectiveness, wide spectrum for various species, and low persistence. They are widely used all over the world because they are an attractive alternative to persistent organochlorine pesticides and possess the ability to rapidly degrade under natural conditions sunlight, air, and soil [2]. The carbamate form is a class of highly effective commercial pesticides and they are preferred worldwide since 1960. They are known as N-substituted carbamic acid esters [3]. As a carbamate pesticide, propoxur (PRO) was introduced by German chemical manufacturer Bayer in 1975. It is used against insect pests such as chewing and sucking insects, flies, moths, cockroaches, ants, crickets, and mosquitoes [4]. The toxic properties are based on inhibition of acetyl cholinesterase in the central nervous system, leading to paralysis in insects and mammals [5]. Fenitrothion (FEN) is one of the most common organophosphorus insecticides frequently used to control insects in crops, such as vegetables, rice, fruits, coffee, soybeans, cotton, and cereals. It is also employed to rein the mosquito vector carrying. FEN is partially water-soluble and therefore may enter the ground and underground water [6,7]. Molecular formulas of PRO and FEN pesticides were given in Figure 1.<smiles>CNC(=O)Oc1ccccc1OC(C)C</smiles>

Propoxur

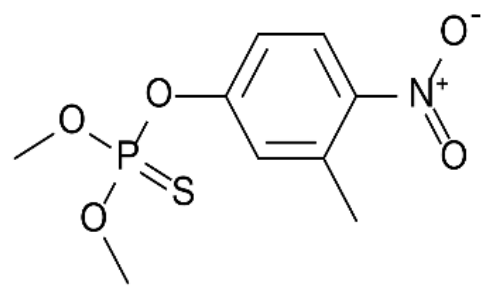

Fenitrothion

Figure 1. Molecular formulas of the studied pesticides.

Contamination of surface water and groundwater with hazardous compounds has attracted increasing attention in recent decades all over the world [8]. According to the European Union (EU) Directive on water quality (98/83/CE) [9], the maximum admissible concentration (MAC) for pesticides is $0.1 \mu \mathrm{g} \mathrm{L}^{-1}$ for each individual substance and $0.5 \mu \mathrm{g} \mathrm{L}^{-1}$ is the maximum allowed for the total concentration of all organophosphorus pesticides. For this reason, development of easy applicable, sensitive, cheap, and correct analysis methods for pesticide molecules is needed as an alternative to the time consuming and expensive chromatographic laboratory techniques currently in use [10]. A lot of analytical method and pretreatment procedures were studied and published for propoxur and fenitrothion pesticides in various samples such as plant and animal tissues, vegetables, fruits, food grains, different type of waters, and milk samples. These methods are generally based on pretreatment procedures or expensive hybrid instrumental tools [3-5,11-14].

Trace analysis of the analytes in complex samples generally requires a pretreatment step to isolate and enrich the target analytes, and to reduce the matrix interferences prior to instrumental determinations [15]. The most common used pretreatment procedure is solid phase extraction (SPE) based on column or batch type because the application is easy and available for automation. Although many sample preparation techniques have been already used by analytical chemists, solid-phase extraction (SPE) based approaches are mostly preferred in routine analytical process because of its 
versatility and the possibility of using different materials as adsorbent [16-18]. There are a variety of sorbents available for various target ions or molecules. However, separation scientists have been trying to develop a better one every day. An appropriate adsorbent is very crucial for the efficient extraction of the analyte; therefore, the exploration of new adsorbents has received growing attention. Among adsorbent materials, carbon materials have attracted substantial interest due to their high surface area, excellent adsorption capacity, good chemical stability, and low cost [19,20]. Magnetic solid-phase extraction (MSPE) is based on magnetic particles as adsorbent that makes the sample preparation procedure simple and fast [21]. In MSPE, target analytes are adsorbed on the surface of magnetic particles and separated from the sample solution by an external magnetic force easily [16,22]. Iron based magnetic particles have significant advantages including primarily price, environmentally safe, high specific surface area, physical and chemical stability, and compatibility for biomedical applications [23]. In addition to these advantageous properties, their most favorable characteristics include easier separation through an external magnetic field, and the absence of internal diffusion resistance [24-26]. Moreover, the required selectivity can be obtained by covering the core with various functional groups for target molecules. These are ideal properties expected from an effective preconcentration and separation method $[27,28]$.

The present study reports a simple, rapid, and convenient procedure based on magnetic solid-phase extraction and HPLC-DAD for the trace determination of propoxur and fenitrothion in environmental water samples. The used magnetic particles as solid-phase sorbent was synthetized and characterized for this study. The sensitivity in this MSPE approach is mainly based on synthesized magnetic particle modified by decanoic acid. The finally, the procedure was applied to water samples successfully.

\section{Results and Discussions}

\subsection{Characterization of Magnetic Nanoparticles}

Characterization of the newly developed magnetic material was carried out by FTIR, XRD, SEM-EDX, and TGA analysis. Structure of magnetic sorbent was provided and explained in every step of characterization.

Figure 2 illustrates the FT-IR spectrum of the $\mathrm{Fe}_{3} \mathrm{O}_{4}$ and decanoic acid modified $\mathrm{Fe}_{3} \mathrm{O}_{4}$ materials. A specific strong peak around $650 \mathrm{~cm}^{-1}$ belongs to $\mathrm{Fe}-\mathrm{O}$ vibration modes (Figure 2A). When the FT-IR spectrum of decanoic acid modified $\mathrm{Fe}_{3} \mathrm{O}_{4}$ is examined, important shifts in spectrum region and important differences at peak intensities and shapes are seen (Figure 2B). Characteristic peaks at around 1010 and $796 \mathrm{~cm}^{-1}$ are corresponding to $\mathrm{Si}-\mathrm{O}-\mathrm{CH}_{3}$ and $\mathrm{Si}-\mathrm{O}$ vibrations, respectively. The new peaks around $1620 \mathrm{~cm}^{-1}$ correspond to $\mathrm{C}=\mathrm{O}$ vibration in decanoic acid (Figure $2 \mathrm{~B}$ ).

In XRD analysis, Figure 3 shows the XRD patterns of decanoic acid modified $\mathrm{Fe}_{3} \mathrm{O}_{4}$ material. The XRD pattern causes a reflection peak at $2 \theta=30.3,35.7$, and $57.2^{\circ}$ that can be assigned to $\mathrm{Fe}_{3} \mathrm{O}_{4}$, and $2 \theta=62.9^{\circ}$ that can be assigned to $\alpha-\mathrm{Fe}_{2} \mathrm{O}_{3}$.

The morphological structure, particles size of the synthesized $\mathrm{Fe}_{3} \mathrm{O}_{4}$ and decanoic acid modified $\mathrm{Fe}_{3} \mathrm{O}_{4}$ materials were searched by FE-SEM (Field Emission Scanning Electron Microscope), SEM-EDX, and SEM-mapping analysis. The obtained results showed that the average size of $\mathrm{Fe}_{3} \mathrm{O}_{4}$ particles were $108 \mathrm{~nm}$ (Figure 4A). After modification of $\mathrm{Fe}_{3} \mathrm{O}_{4}$ particles with tetraethyl orthosilicate and decanoic acid, as well as morphological structure, it was seen that the morphological structure of the material changed completely, and the size of particles increased (Figure 4B). Moreover, formation of $\mathrm{Fe}_{3} \mathrm{O}_{4}$ particles and successful connection of tetraethyl orthosilicate (TEOS) group on the $\mathrm{Fe}_{3} \mathrm{O}_{4}$ particles were proven by SEM-EDX analysis (Figure 4C). Homogeneous dispersion of $\mathrm{Fe}_{3} \mathrm{O}_{4}$ particles in the whole structure was proved by mapping analysis (Figure 4D). 


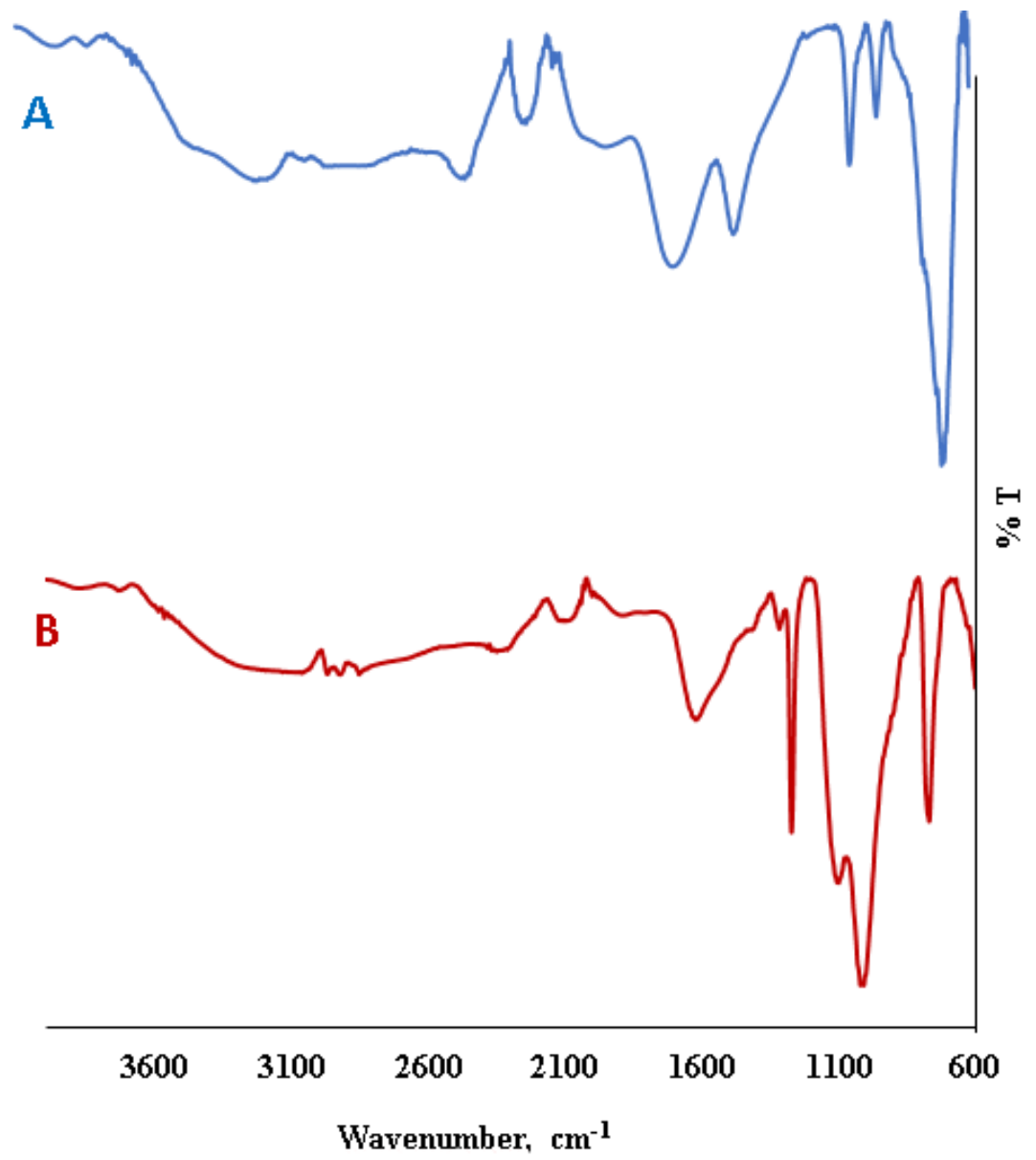

Figure 2. FT-IR spectrum of the $\mathrm{Fe}_{3} \mathrm{O}_{4}$ nanoparticles (A) and decanoic acid modified $\mathrm{Fe}_{3} \mathrm{O}_{4}$ nanoparticles (B).

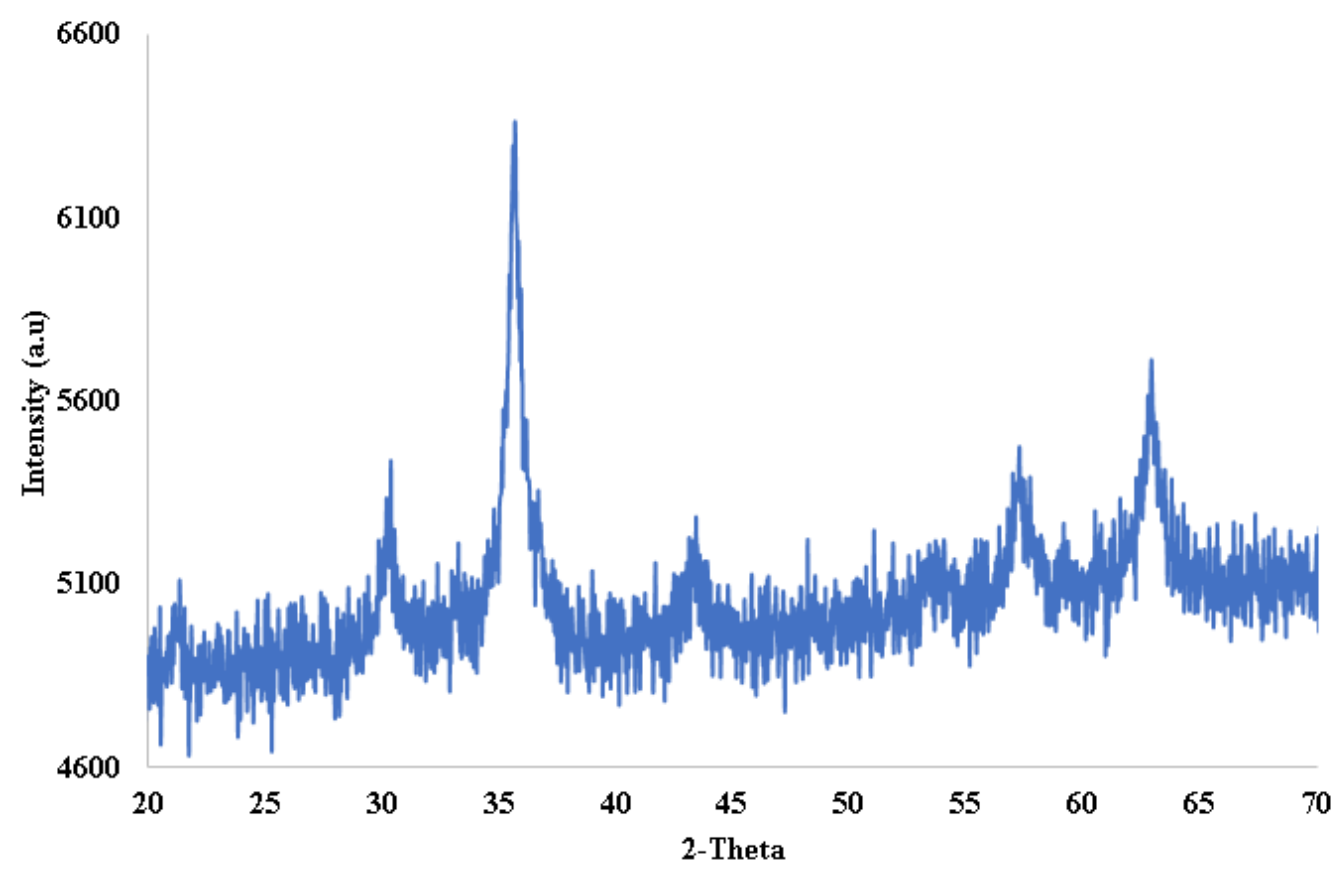

Figure 3. XRD patterns of the decanoic acid modified $\mathrm{Fe}_{3} \mathrm{O}_{4}$ material. 


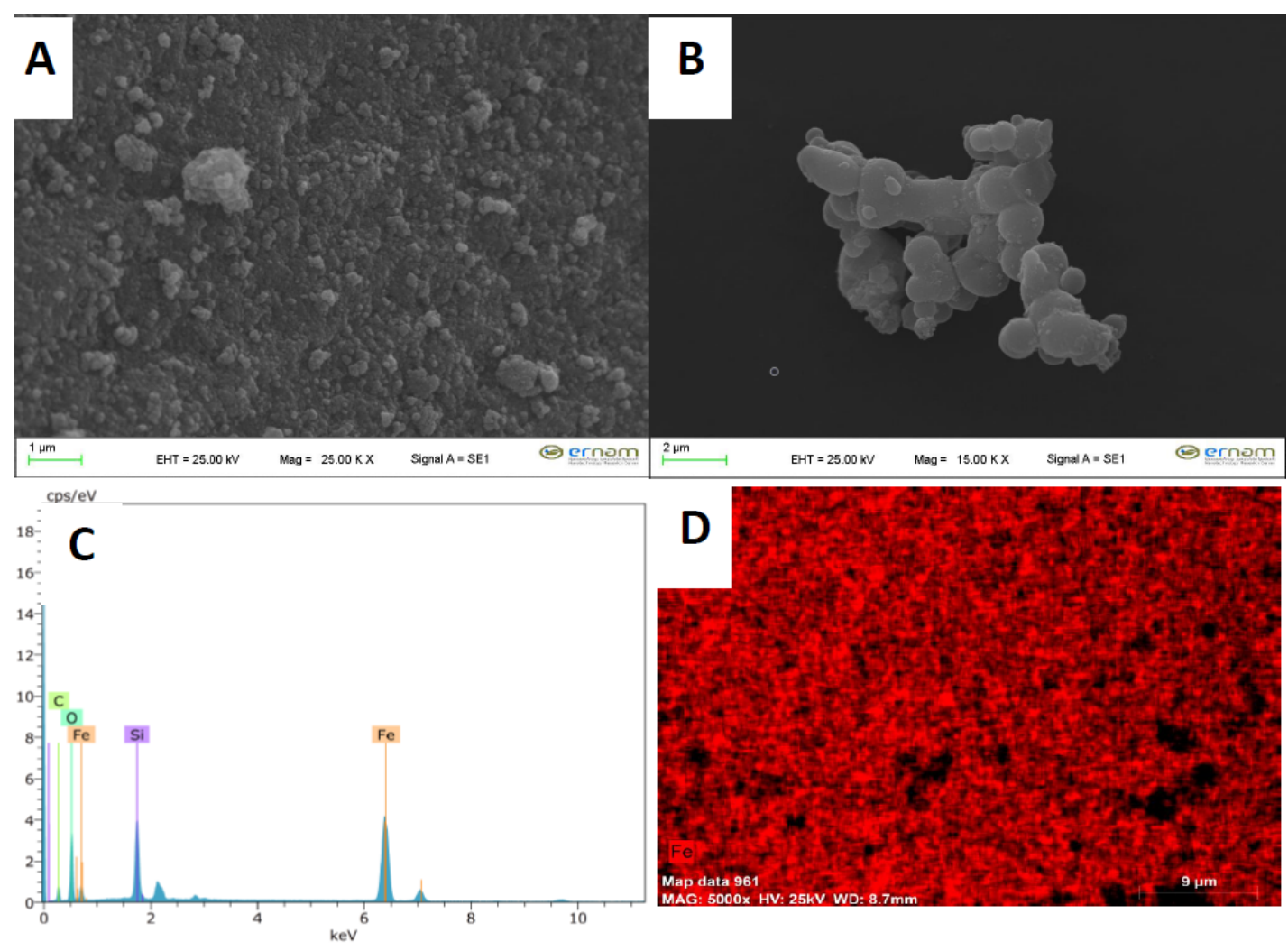

Figure 4. (A) Results of FE-SEM analysis of $\mathrm{Fe}_{3} \mathrm{O}_{4}$ nanoparticles, (B) decanoic acid modified $\mathrm{Fe}_{3} \mathrm{O}_{4}$ nanoparticles, (C) EDX analysis of decanoic acid modified $\mathrm{Fe}_{3} \mathrm{O}_{4}$ nanoparticles, and (D) mapping analysis of decanoic acid modified $\mathrm{Fe}_{3} \mathrm{O}_{4}$ nanoparticles.

In thermo gravimetric analysis, the TGA curve of decanoic acid modified $\mathrm{Fe}_{3} \mathrm{O}_{4}$ is shown in Figure 5. As can be seen in Figure 5, the total weight loss of the material was approximately $8 \%$ and the TGA process can be divided into three distinct stages. The first weight loss was at approximately $50-240{ }^{\circ} \mathrm{C}$, corresponding to the evaporation of moisture. The second major weight loss (around $4 \%$ ) was at approximately $240-400{ }^{\circ} \mathrm{C}$ corresponding to conversion of silane group to $\mathrm{SiO}_{2}$ and the last weight loss (around $2 \%$ ) was at approximately $400-700{ }^{\circ} \mathrm{C}$ corresponding to decomposition of decanoic acid.

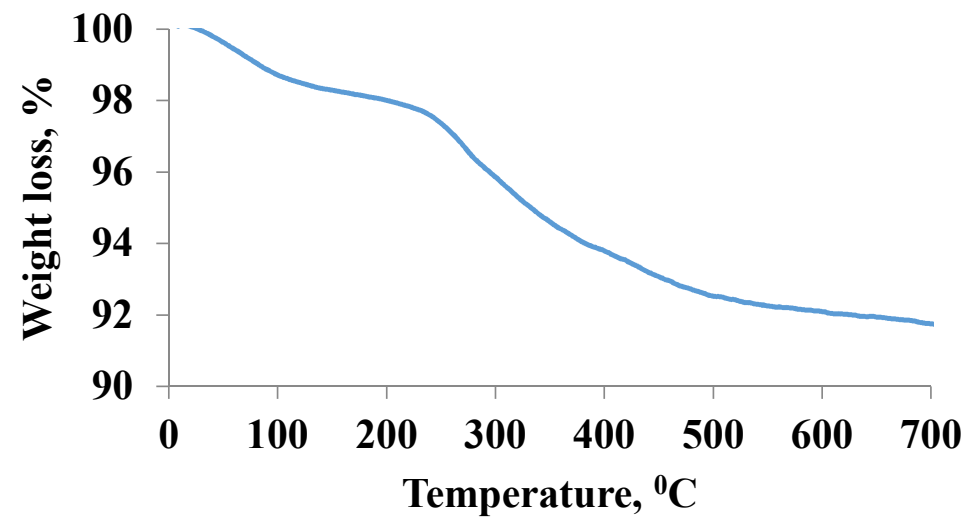

Figure 5. TGA analysis of the decanoic acid modified $\mathrm{Fe}_{3} \mathrm{O}_{4}$ nanoparticles.

\subsection{Optimization of Magnetic Solid-Phase Extraction Procedure}

Each parameter affecting extraction efficiency of the magnetic nanoparticles was studied and optimized in detail. All optimization steps were studied using model solutions containing $200 \mathrm{ng}$ 
$\mathrm{mL}^{-1}$ propoxur and fenitrothion pesticides. During the optimization of parameters, one parameter is systematically changed while other parameters are kept at constant level. Initial conditions of MSPE procedure: $50 \mathrm{mg}$ of magnetic material, $2 \mathrm{~mL}$ of BR buffer, $60 \mathrm{~min}$ of adsorption time, $1 \mathrm{~mL}$ of organic solvent, $60 \mathrm{~s}$ of vortex. All experiments were carried out in $50 \mathrm{~mL}$ of falcon tube. The studies have been started at a fixed ratio sample/sorbent $(50 \mathrm{~mL}$ of sample/50 $\mathrm{mg}$ sorbent). Then, all variables were optimized step-by-step by repeating three times $(n=3)$. The analytical signal increased by every step of the optimization and finally arrived at a maximum value for an ideal and sensitive determination of pesticides.

\subsubsection{Effect of $\mathrm{pH}$ on Extraction Efficiency}

Propoxur and fenitrothion pesticides have functional groups affected by the matrix $\mathrm{pH}$. In addition, surface charge of magnetic particles also changes with acidity of the medium. Therefore, an ideal $\mathrm{pH}$ value should be determined as the first optimization parameter. The possible major interactions between target molecules and magnetic particles are hydrophobic interactions and $\pi-\pi$ stacking. Therefore, most of the analyte molecules are considered in molecular form for a good extraction efficiency. Additionally, carbamate pesticides exhibit the weak alkaline property (pKa values around 12) and would suffer from hydrolysis in strong alkaline conditions, especially when the $\mathrm{pH}$ is above 10. The $\mathrm{pH}$ of preconcentration medium based on magnetic solid-phase extraction was evaluated in the range of 2-10 by using a BR buffer system. As can be seen in Figure 6, intensity of analytical signals arrived at a maximum value of $\mathrm{pH} 7.0$ for both pesticides. Interactions between analyte and magnetic sorbents are observed in the highest level, so next studies were continued by using pH 7.0 buffers. This value is also good for the application of the method to environmental samples in their own $\mathrm{pH}$ which is close to neutral range.

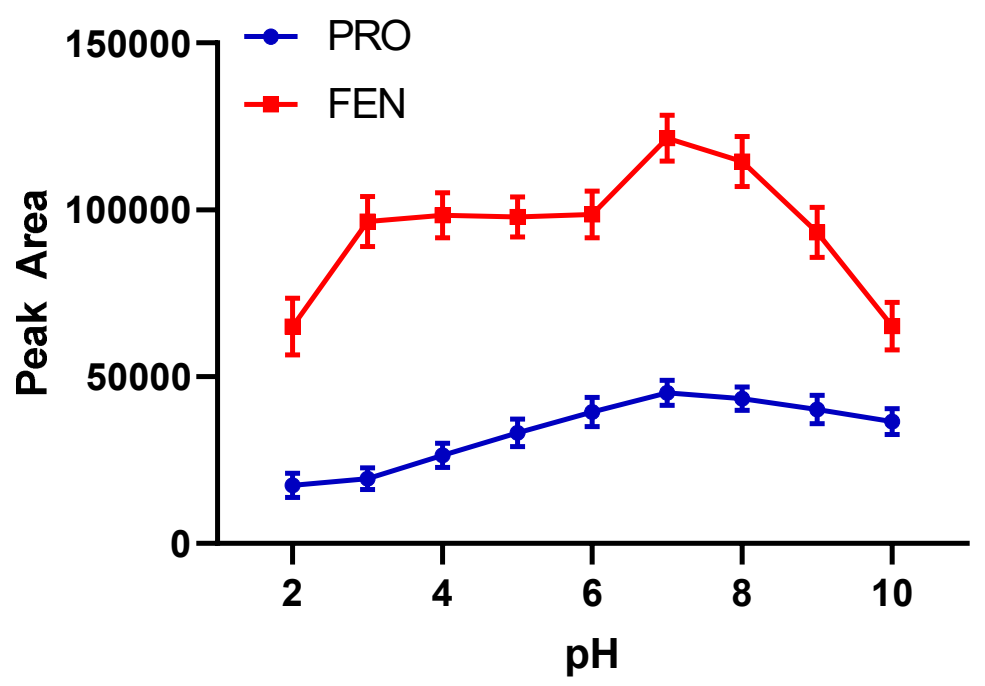

Figure 6. The effect of $\mathrm{pH}$ on extraction efficacy $(n=3)$.

\subsubsection{Selection of Desorption Solvent and Its Optimum Volume}

The magnetic solid-phase extraction process can be evaluated in two main steps: Adsorption and desorption of target molecules. In the first step, the required conditions for adsorption are enhanced and optimized such as $\mathrm{pH}$, type of magnetic particles, and interaction time. In the second step, the conditions are examined for complete desorption of retained pesticide molecules from the surface of magnetic particles. Desorption is controlled by various mechanisms such as electrostatic interactions and dipole-dipole interactions. In order to find the best suitable solvent for both molecules, polar and nonpolar solvents were studied, and analytical signals were followed for each option. $1 \mathrm{~mL}$ of each solvent were used for desorption experiments. The results were shown in Figure 7. Intensity of 
analytical signals obtaining from 2-propanol for pesticides were higher than other solvents. Therefore, next studies were continued by using this solvent.

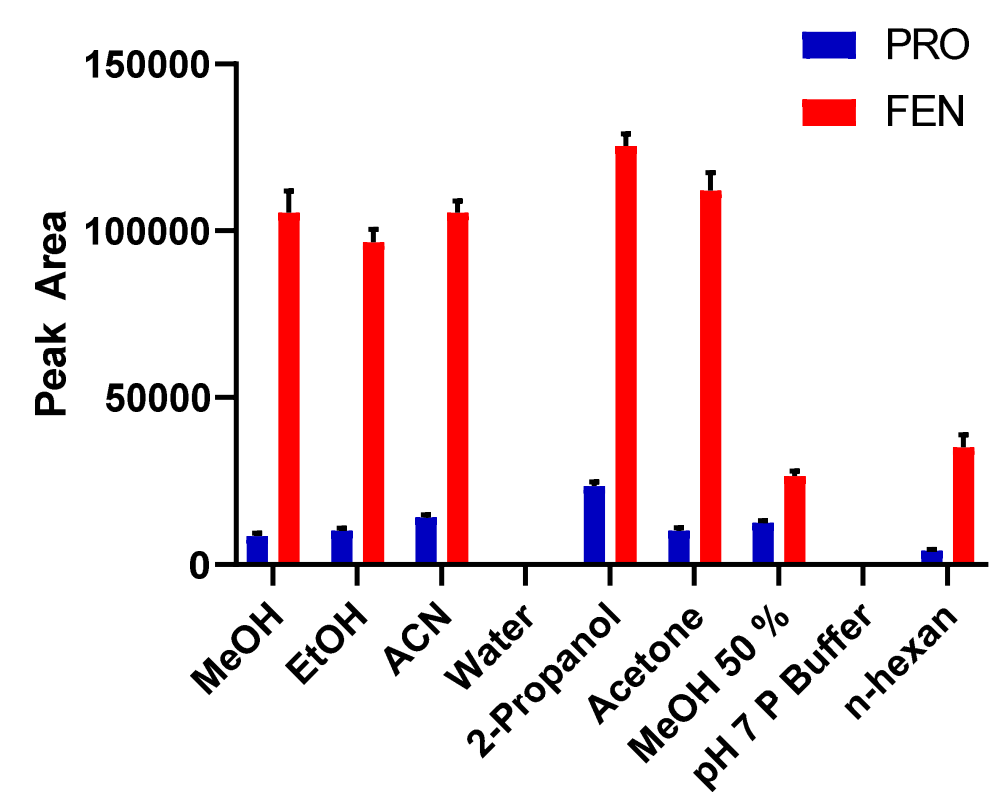

Solvents for Desorption

Figure 7. Selection of appropriate desorption solvent $(n=3)$.

The amount of desorption solvent is another important parameter in order to obtain a high preconcentration factor. The final volume of solution determines efficiency of preconcentration procedure because initial volume is the same for all solutions. Therefore, it is aimed at the possible lowest volume of desorption solvent. However, there is another problem in this step about desorption efficiency. If the volume of desorption solvent is not enough to remove all retained molecules from the surface of particles, quantitate results are not obtained in the final step. Therefore, the volume of solvent is crucial in preconcentration experiments. After 2-propanol was chosen as an ideal solvent, its volume was optimized in the range of 200-1300 $\mu \mathrm{L}$. The results were given in Figure 8. As expected, the analytical signals increased by volume initially and then decreased again due to dilution effect. The peak point for both pesticides was determined as $400 \mu \mathrm{L}$ of 2-propanol.

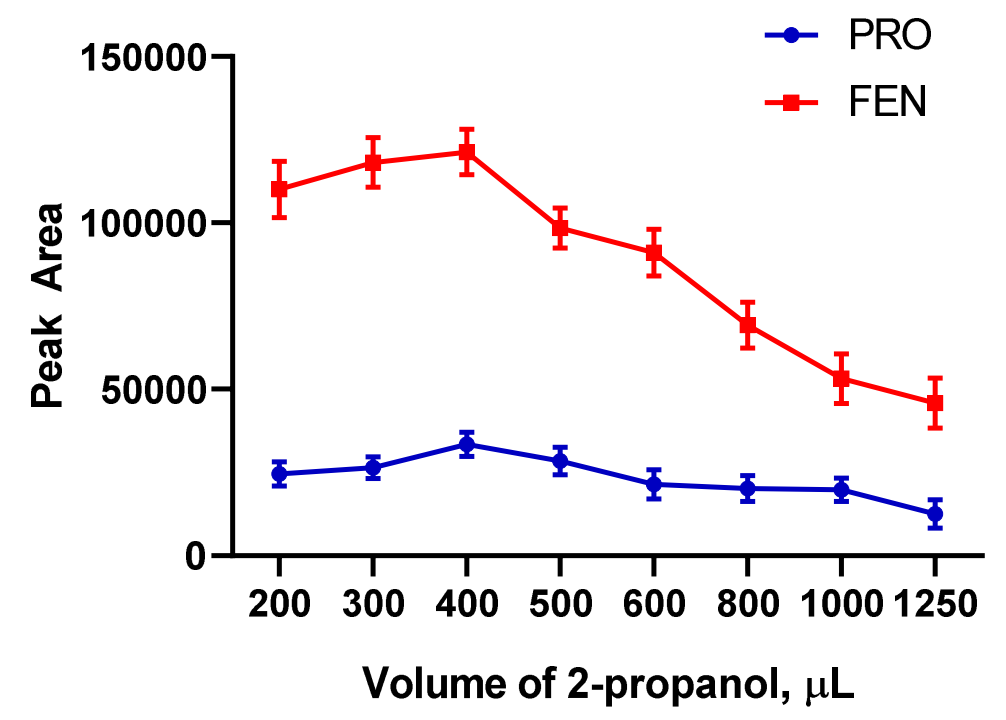

Figure 8. Optimization for volume of desorption solvent $(n=3)$. 


\subsubsection{Optimization of Shaking Time for Adsorption and Vortexing Time for Desorption}

Retention of pesticide molecules on the surface of magnetic particles needs adequate contact time. For this purpose, an orbital shaker was used at $80 \mathrm{rpm}$ rate. The model solutions containing pesticides were placed on an orbital shaker and interaction time was evaluated in the range of 0-90 $\mathrm{min}$. It is expected that an ideal method should be completed in the shortest time possible. The optimal time should be enough for a quantitate extraction and not much longer for fast analysis. As can be seen in Figure 9, $30 \mathrm{~min}$ as interaction time is enough for both pesticides. There is no meaningful change after $30 \mathrm{~min}$. Therefore, the samples were kept on an orbital shaker for $30 \mathrm{~min}$ in next studies.

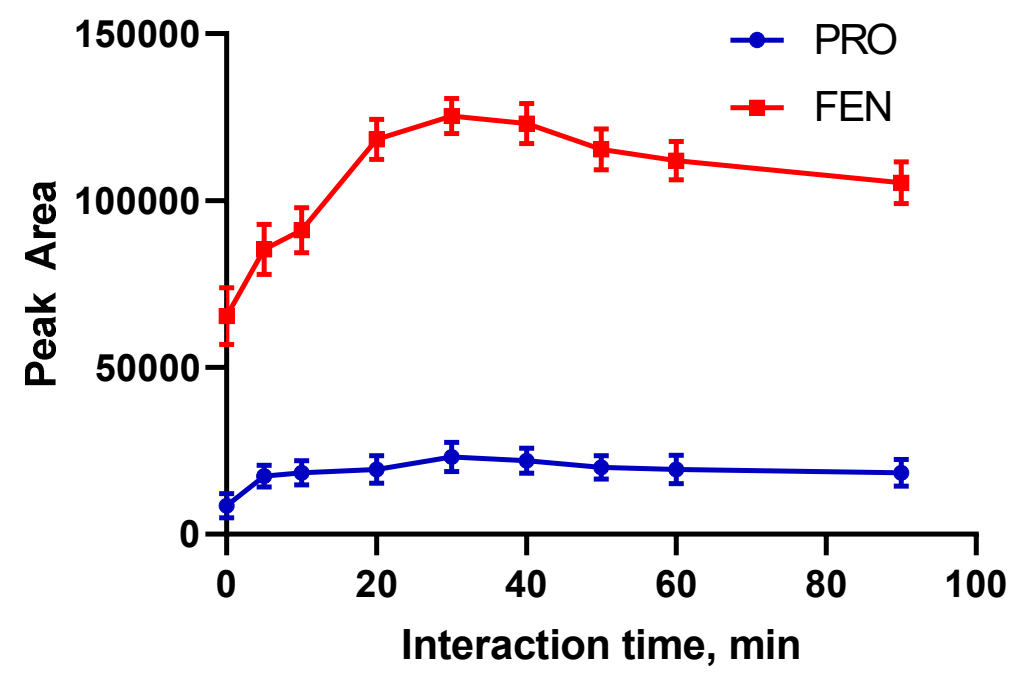

Figure 9. Optimization of adsorption time $(n=3)$.

The effect of vortex time in the desorption process was also optimized in the range of 10-120 s. Experiments were repeated by using model solutions including PRO and FEN pesticides at the concentration of $100 \mathrm{ng} \mathrm{mL}^{-1}$. Under the optimization conditions, it was observed that $40 \mathrm{~s}$ is enough for a quantitate desorption of pesticide molecules.

\subsubsection{Reusability of Decanoic Acid Grafted Magnetic Particles}

For an ideal solid phase sorbent, the developed materials are expected to offer several attributes such as cost efficiency, resistance against various chemicals, reusability, environmental-friendly, etc. Reusability is one of the most important characteristics of a solid-phase extraction sorbent because it directly impacts on the analysis costs and durability of the method. In order to assess reusability of magnetic particles, experimental studies were repeated with model solutions at the same concentration (involving $100 \mathrm{ng} \mathrm{mL}^{-1}$ of each pesticide). As the result revealed, the peak area of pesticides did not change significantly after 10 cycle use. The magnetic particles were washed with $2 \mathrm{~mL}$ of 2-propanol and $1 \mathrm{~mL}$ methanol after every use. Then, it was dried and re-weighed again. Changes in peak area of pesticides were lower than $5 \%$ after 10 uses.

\subsection{Method Validation}

Method validation has been performed as recommended in the International Conference on Harmonization of Technical Requirements for Registration of Pharmaceuticals for Human Use (ICH) [28-30].

\subsubsection{Linearity}

The linearity of the method was studied using twelve spiked levels (in the range of 5-800 and $10-800 \mathrm{ng} \mathrm{mL}^{-1}$ ) for both pesticides and each solution were analyzed by the developed MSPE followed 
by a HPLC-PDA technique. A good linearity was obtained with correlation coefficients in the range of 0.9908-0.9954 (Table 1).

Table 1. Analytical figures of merit of the proposed method.

\begin{tabular}{ccccc}
\hline \multirow{2}{*}{ Parameter } & \multicolumn{2}{c}{ Before MSPE } & \multicolumn{2}{c}{ After MSPE } \\
\cline { 2 - 5 } & Fenitrothion & Propoxur & Fenitrothion & Propoxur \\
\hline Linear range & $2.0-20.0 \mu \mathrm{g} \mathrm{mL}^{-1}$ & $2.0-20.0 \mu \mathrm{g} \mathrm{mL}^{-1}$ & $5.0-800.0 \mathrm{ng} \mathrm{mL}^{-1}$ & $10.0-800.0 \mathrm{ng} \mathrm{mL}^{-1}$ \\
LOD & $0.57 \mu \mathrm{gL}^{-1}$ & $0.57 \mu \mathrm{mL}^{-1}$ & $1.43 \mathrm{ng} \mathrm{mL}^{-1}$ & $3.15 \mathrm{ng} \mathrm{mL}^{-1}$ \\
LOQ & $1.88 \mu \mathrm{g} \mathrm{m}^{-1}$ & $1.88 \mu \mathrm{g} \mathrm{m}^{-1}$ & $4.93 \mathrm{ng} \mathrm{mL}^{-1}$ & $9.86 \mathrm{ng} \mathrm{mL}^{-1}$ \\
RSD $(\%)$ & 3.8 & 3.6 & 2.9 & 3.2 \\
Slope & 10.218 & 1.473 & 1348.8 & 173.76 \\
$\left.\mathrm{R}^{2}\right)$ & 0.9972 & 0.9985 & 0.9954 & 0.9908 \\
Preconcentration Factor $^{\text {a }}$ & - & - & 125 & 125 \\
Enhancement Factor $^{\mathrm{b}}$ & - & - & 132 & 118 \\
\hline
\end{tabular}

${ }^{\text {a }}$ Preconcentration factor is defined as the ratio of the initial solution volume $(50 \mathrm{~mL})$ to the volume of final solution $(400 \mu \mathrm{L}) ;{ }^{b}$ Enhancement factor is defined as ratio of slope of calibration before and after MPSE.

\subsubsection{Accuracy and Precision}

The accuracy of the method was validated by the spiked recovery test which is described below: Two concentration levels of the two analytes (100 and $200 \mathrm{ng} \mathrm{mL}^{-1}$ ) were added to a blank and samples separately, and then the resulting two sets of spiked samples were extracted and analyzed. The spiked recoveries were between $94.2 \%$ and $107.4 \%$ with RSD values from $2.8 \%$ to $6.5 \%$ (Table 2 ), which showed that the proposed method is accurate and reliable.

Table 2. Relative recovery values and reproducibility data for propoxur and fenitrothion pesticides in various environmental water samples after MSPE procedure ( $\mathrm{N}: 3)$.

\begin{tabular}{|c|c|c|c|c|c|c|c|}
\hline \multirow[t]{2}{*}{ Sample } & \multirow{2}{*}{$\begin{array}{c}\text { Added } \\
\mathrm{ng} \mathrm{mL}^{-1}\end{array}$} & \multicolumn{2}{|c|}{$\begin{array}{l}\text { Found } \\
\text { ng } m L^{-1}\end{array}$} & \multicolumn{2}{|c|}{ RSD \% } & \multicolumn{2}{|c|}{ Recovery \% } \\
\hline & & Propoxur & Fenitrothion & Propoxur & Fenitrothion & Propoxur & Fenitrothion \\
\hline \multirow{3}{*}{$\begin{array}{c}\text { River } \\
\text { water I }\end{array}$} & - & $<\mathrm{LOD}$ & $<\mathrm{LOD}$ & - & - & - & - \\
\hline & 100.0 & $94.2 \pm 2.7$ & $103.2 \pm 3.4$ & 2.8 & 3.3 & 94.2 & 103.2 \\
\hline & 200.0 & $206.1 \pm 13.5$ & $202.4 \pm 8.4$ & 6.5 & 4.1 & 103.5 & 101.2 \\
\hline \multirow{3}{*}{$\begin{array}{c}\text { Lake water } \\
\text { II }\end{array}$} & - & $<\mathrm{LOD}$ & $<\mathrm{LOD}$ & - & - & - & - \\
\hline & 100.0 & $97.9 \pm 3.8$ & $99.5 \pm 2.9$ & 3.9 & 2.9 & 97.9 & 99.5 \\
\hline & 200.0 & $192.1 \pm 10.5$ & $203.7 \pm 9.8$ & 5.5 & 4.8 & 96.1 & 101.8 \\
\hline \multirow{3}{*}{$\begin{array}{l}\text { Pond } \\
\text { water }\end{array}$} & - & $<\mathrm{LOD}$ & $<\mathrm{LOD}$ & - & - & - & - \\
\hline & 100.0 & $107.4 \pm 3.6$ & $95.8 \pm 3.9$ & 3.4 & 4.0 & 107.4 & 95.8 \\
\hline & 200.0 & $193.4 \pm 8.9$ & $205.8 \pm 8.5$ & 4.6 & 4.1 & 96.7 & 102.9 \\
\hline
\end{tabular}

\subsubsection{Limits of Detection and Quantification}

The LOD and LOQ values were calculated from the calibration curve obtained from model solutions [31,32] and the data are presented in Table 1. LOD and LOQ values were calculated at 3.3 and $10 \sigma / S$, respectively, where $\sigma$ is the standard deviation of the intercept and $S$ is the slope of the regression line determined from the calibration curve.

\subsubsection{Selectivity}

The selectivity of the method is the ability to distinguish between the target analytes and other substances or interferences in the real samples. In order to determine the selectivity, a sequence of blank tomato samples obtained from the local market was subjected to extraction and analysis. No interference peaks were observed within the retention time window for all the inspected samples. 


\subsubsection{Robustness}

The robustness of the developed method was examined by making small but deliberate variations in parameters such as flow rate of the mobile phase $\left(1.10,1.20\right.$, and $\left.1.30 \mathrm{~mL} \mathrm{~min}^{-1}\right)$, mobile phase composition in the isocratic elution $(75 \% \mathrm{ACN}, 70 \% \mathrm{ACN}, 65 \% \mathrm{ACN}$, column temperature $(35,40$, $\left.45{ }^{\circ} \mathrm{C}\right)$, injection volume $(8,10,12 \mu \mathrm{L})$, amount of magnetic sorbent $(45,50,55 \mathrm{mg})$, and $\mathrm{pH}$ of the sample matrix $(6.5,7.0,7.5)$. Insignificant differences in peak areas were observed with the RSD values in the range of 1.1-5.2 for all variables. The results suggested that these variations had little effect on the method performance, demonstrating the robustness of the method.

\subsubsection{Application in Real Sample}

The newly developed MSPE coupled with the HPLC-PDA technique was applied to determine residues of two pesticides in environmental water samples collected from Sivas city, Turkey. The results showed in Table 2 that none of the studied pesticide was detected in samples.

\subsubsection{Performance Comparison between the Current and Other Reported Methods}

The performance of the proposed method was compared with other sample pretreatment methods from the viewpoint of LOD, linear range, sample, and detection tool. As shown in Table 3, the newly developed MSPE-HPLC-PDA method has a good and useful linear range for FEN and PRO pesticides compared to other reported methods, demonstrating that the proposed method is sensitive, efficient, and repeatable. Spectrophotometric and GC based methods have problems about selectivity and sensitivity $[13,33,34]$. The proposed method has a wider linear range than most of methods in literature $[6,14,16,19,35,36]$.

Table 3. Comparison of the new method with other reported methods.

\begin{tabular}{|c|c|c|c|c|c|c|}
\hline $\begin{array}{l}\text { Preconcentration } \\
\text { Method }\end{array}$ & $\begin{array}{l}\text { Determination } \\
\text { Method }\end{array}$ & $\begin{array}{c}\text { Target } \\
\text { Molecule }\end{array}$ & LOD & Linear Range & Applications & Reference \\
\hline $\begin{array}{l}\text { Quenchers based } \\
\text { method }\end{array}$ & $\begin{array}{l}\text { Gas } \\
\text { chromatography-flame } \\
\text { photometric detector }\end{array}$ & Fenitrothion & $\begin{array}{l}0.005 \mu \mathrm{g} \\
\mathrm{mL}^{-1}\end{array}$ & $\begin{array}{c}0.005-5.0 \mu \mathrm{g} \\
\mathrm{mL}^{-1}\end{array}$ & Tomatoes & [13] \\
\hline $\begin{array}{c}\text { Dispersive } \\
\text { solid-phase } \\
\text { microextraction }\end{array}$ & HPLC-UV & Fenitrothion & $0.1 \mu \mathrm{g} \mathrm{L}^{-1}$ & $0.3-50.0 \mu \mathrm{g} \mathrm{L}^{-1}$ & $\begin{array}{l}\text { Water and fruit } \\
\text { samples }\end{array}$ & [6] \\
\hline $\begin{array}{l}\text { Electrospun } \\
\text { polystyrene } \\
\text { nanofibers as } \\
\text { solid-phase } \\
\text { extraction sorbent }\end{array}$ & HPLC-DAD & Fenitrothion & $0.07 \mathrm{ng} \mathrm{mL}^{-1}$ & $\begin{array}{c}0.5-50.0 \mathrm{ng} \\
\mathrm{mL}^{-1}\end{array}$ & $\begin{array}{l}\text { Environmental } \\
\text { waters }\end{array}$ & [14] \\
\hline $\begin{array}{c}\text { Magnetite } \\
\text { octadecylsilane } \\
\text { nanoparticles }\end{array}$ & HPLC-UV & Fenitrothion & $\begin{array}{l}0.014 \mathrm{ng} \\
\mathrm{mL}^{-1}\end{array}$ & $0.03-30 \mathrm{ng} \mathrm{mL}^{-1}$ & $\begin{array}{l}\text { Environmental } \\
\text { water }\end{array}$ & [35] \\
\hline $\begin{array}{l}\text { Magnetic } \\
\text { solid-phase } \\
\text { extraction }\end{array}$ & Spectrophotometry & Fenitrothion & $0.5 \mathrm{ng} \mathrm{mL}^{-1}$ & $2-230 \mathrm{ng} \mathrm{mL}^{-1}$ & $\begin{array}{l}\text { Environmental } \\
\text { and biological } \\
\text { samples }\end{array}$ & [34] \\
\hline $\begin{array}{l}\text { Magnetic } \\
\text { solid-phase } \\
\text { extraction }\end{array}$ & $\begin{array}{l}\text { Gas chromatographic } \\
\text { determination }\end{array}$ & Fenitrothion & $3.9 \mathrm{ng} \mathrm{mL}^{-1}$ & $\begin{array}{c}10-50000 \mathrm{ng} \\
\mathrm{mL}^{-1}\end{array}$ & Fruit juices & [33] \\
\hline $\begin{array}{l}\text { Magnetic } \\
\text { solid-phase } \\
\text { extraction }\end{array}$ & HPLC-UV & Fenitrothion & $\begin{array}{l}0.2-0.8 \mu \mathrm{g} \\
\mathrm{L}^{-1}\end{array}$ & $1-100 \mu \mathrm{g} \mathrm{L}^{-1}$ & Water samples & [16] \\
\hline $\begin{array}{l}\text { Magnetic } \\
\text { solid-phase } \\
\text { extraction }\end{array}$ & HPLC-UV & Propoxur & $0.2 \mathrm{ng} \mathrm{g}^{-1}$ & $1.0-100.0 \mathrm{ng} \mathrm{g}^{-1}$ & Apple sample & [19] \\
\hline $\begin{array}{l}\text { Solid-phase } \\
\text { extraction }\end{array}$ & HPLC-UV & Propoxur & $0.05 \mathrm{ng} \mathrm{g}^{-1}$ & $0.2-80.0 \mathrm{ng} \mathrm{g}^{-1}$ & $\begin{array}{l}\text { Cucumber and } \\
\text { watermelon } \\
\text { samples }\end{array}$ & [36] \\
\hline \multirow{2}{*}{$\begin{array}{l}\text { Magnetic } \\
\text { solid-phase } \\
\text { extraction } \\
\end{array}$} & \multirow{2}{*}{ HPLC-PDA } & \multirow{2}{*}{$\begin{array}{l}\text { Propoxur } \\
\text { Fenitrothion }\end{array}$} & $1.43 \mathrm{ng} \mathrm{mL}^{-1}$ & $5-800 \mathrm{ng} \mathrm{mL}^{-1}$ & \multirow{2}{*}{$\begin{array}{l}\text { Environmental } \\
\text { waters }\end{array}$} & \multirow[t]{2}{*}{ This Study } \\
\hline & & & $3.15 \mathrm{ng} \mathrm{mL}^{-1}$ & $10-800 \mathrm{ng} \mathrm{mL}^{-1}$ & & \\
\hline
\end{tabular}




\section{Materials and Methods}

\subsection{Reagents and Standard Solutions}

All reagents used were of analytical grade. Ultra-pure water with a resistivity of $18.2 \mathrm{M} \Omega$ was used in all experiments and was provided by an ELGA (Flex III, Lane End, UK) water purification system. Fenitrothion and propoxur pesticide standard were purchased from Sigma-Aldrich (Steinheim, Germany). HPLC grade solvents, methanol, acetonitrile, and isopropyl alcohol were from Merck (Darmstadt, Germany). The stock solutions (200 mg/L) of pesticides were prepared by dissolving each of them in methanol. The working solutions were prepared by appropriate dilution of the stock solutions with double-distilled water. All the standard solutions were stored at $4{ }^{\circ} \mathrm{C}$ and brought to ambient temperature just prior to use.

A mixture stock solution containing propoxur and fenitrothion at $100.0 \mathrm{ng} \mathrm{mL} \mathrm{m}^{-1}$ was prepared in methanol. A series of standard solutions were prepared by mixing an appropriate amount of the stock solution with methanol in a $10 \mathrm{~mL}$ volumetric flask. $10 \mathrm{mM}$ of Britton Robinson (BR) buffer (10 mM boric acid, $10 \mathrm{mM}$ glacial acetic acid, and $10 \mathrm{mM}$ phosphoric acid), with $100 \mathrm{mM} \mathrm{NaCl}$ was used in all the experiments at different $\mathrm{pH}$ values ranging from $\mathrm{pH}$ 2.0-10.0.

\subsection{Instrumentation}

The chromatographic system used was equipped with a pump model LC20-AD (Shimadzu, Tokyo, Japan), a thermostatic oven, CTO-10 AS (Shimadzu), auto sampler, SIL-20AC (Shimadzu), and a DAD detector model SPD-M20A (Shimadzu). An LC solution software (Shimadzu) was used to transfer data to the computer. A Luna Omega C18 $(250 \times 4.6 \mathrm{~mm}, 5 \mu \mathrm{m})$ column was used for chromatographic separation. A pH meter with a glass-calomel electrode (Selecta, Spain) was used to measure the $\mathrm{pH}$ values. An ultrasonic water bath (Kudos, China) was used for sample preparation.

Previous determinations, all solvents used in the chromatographic system were filtered through a $0.45 \mu \mathrm{m}$ PDFA membrane filter (HNWP, Millipore, Burlington, MA, USA) using a vacuum pump (Buchi, Switzerland) and degassed for $10 \mathrm{~min}$ in an ultrasonic bath (JP Selecta, Barcelona, Spain).

Field-emission scanning electron microscope (Carl Zeiss-Gemini 500, Jena, Germany) was used to examine the morphology of decanoic acid modified magnetic nanoparticles and prove formation of magnetic nanoparticles by EDX analysis. The XRD measurements of decanoic acid modified magnetic nanoparticles was carried out by a Bruker AXS D8 advance X-ray powder diffractometer. FT-IR analysis for decanoic acid modified magnetic nanoparticles was continued by Perkin-Elmer Spectrum 400 FT-IR spectrometer (Waltham, MA, USA). TGA analysis was obtained with a Perkin Elmer-Diamond TGA analyzer. Thermo gravimetric analysis was performed in the range of $50-700{ }^{\circ} \mathrm{C}, \mathrm{N}_{2}$ medium, and $10{ }^{\circ} \mathrm{C} / \mathrm{min}^{-1}$ temperature rise rate.

\subsection{HPLC-PDA Operating Conditions}

The mobile phase composition was ACN:water (70:30) at an isocratic mode throughout the analysis. The flow rate was $1.2 \mathrm{~mL} \mathrm{~min}^{-1}$. The detector wavelength was operated at 269 and $271 \mathrm{~nm}$ for FEN and PRO, respectively. The column temperature was maintained at $30{ }^{\circ} \mathrm{C}$ and injection volume was $10 \mu \mathrm{L}$ for all determinations. The HPLC system was optimized to obtain better signal-to-noise ratio of pesticides in a single chromatographic analysis, the best peak shape, an appropriate run-time, and better peak resolution. The column was flushed with 50\% methanol to completely elute the remaining pesticides and the other organic compounds for $60 \mathrm{~min}$ after each day's work. Peaks in the chromatograms were identified by comparison with retention times and UV spectra of standards. The peak area was considered for quantification. The obtained chromatogram after MSPE by using model solutions including PRO and FEN pesticides was presented at four increasing levels in Figure 10. Absorption spectrums obtained from DAD detector were given as Supplementary 1. 


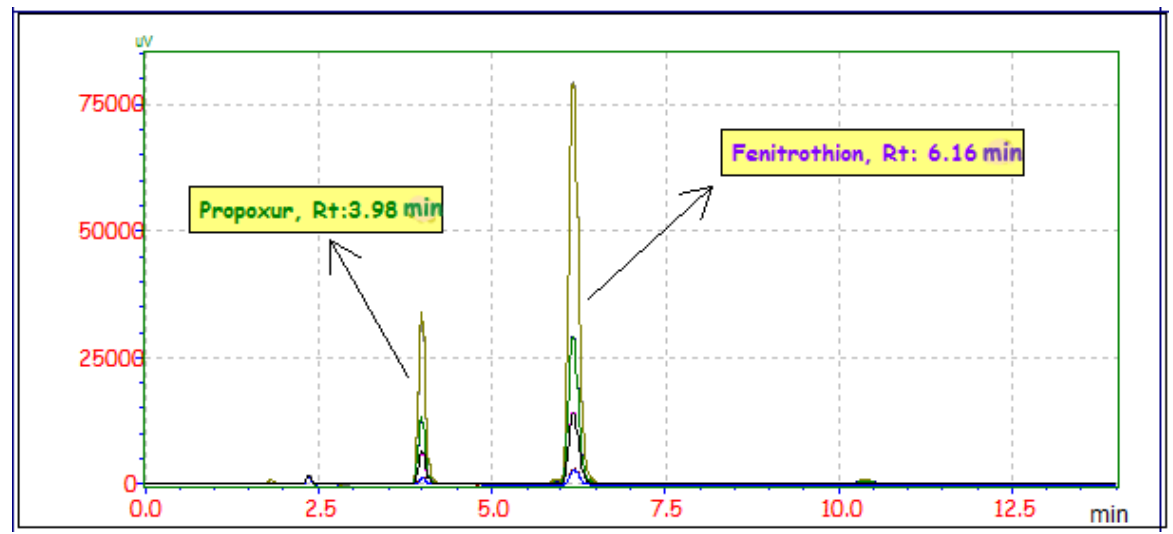

Figure 10. Chromatogram after magnetic solid-phase extraction (MSPE) for pesticide molecules.

\subsection{Synthesis of Magnetic Nanoparticles}

A well-known synthesis approach in literature was used for obtaining magnetic material $[33,34]$. Briefly, a mixture of $0.745 \mathrm{~g}$ of $\mathrm{FeCl}_{3} \cdot 6 \mathrm{H}_{2} \mathrm{O}$ and $0.383 \mathrm{~g}$ of $\mathrm{FeSO}_{4} \cdot 4 \mathrm{H}_{2} \mathrm{O}$ were solved in $50 \mathrm{~mL}$ of $3 \mathrm{M}$ $\mathrm{HCl}$ during stirring at a speed of $600 \mathrm{rpm}$. Then, $100 \mathrm{~mL}$ of $50 \%$ ethanol was added to the solution and temperature was kept on at $85{ }^{\circ} \mathrm{C}$ on a magnetic stirrer. The synthesis reaction was started by dropping $20 \mathrm{~mL}$ of ammonia throughout $10 \mathrm{~min}$ in inert medium of nitrogen gas. The obtained magnetite $\mathrm{Fe}_{3} \mathrm{O}_{4}$ particles were collected from the black solution by the help of external magnet, washed three times by using $50 \% \mathrm{MeOH}$, and dried in the oven at $60^{\circ} \mathrm{C}$ for $6 \mathrm{~h}$.

In the second step; $1 \mathrm{~g} \mathrm{Fe}_{3} \mathrm{O}_{4}$ particles was dispersed in $80 \%$ ethyl alcohol solution including $1 \mathrm{~mL}$ of ammonia. The mixture was stirred at $600 \mathrm{rpm}$ and $80^{\circ} \mathrm{C}$ for $1 \mathrm{~h}$ after $1 \mathrm{~mL}$ of tetraethyl orthosilicate (TEOS) were added to the solution. Then, $200 \mathrm{mg}$ decanoic acid was solved in $2 \mathrm{~mL}$ ethanol and added to the solution on a magnetic stirrer. The mixture was stirred for $6 \mathrm{~h}$. The magnetic particles were removed from the solution by an external magnet and washed five times by $50 \%$ ethanol and then allowed to dry.

\subsection{The Proposed Method of Magnetic Solid-Phase Extraction}

$50 \mathrm{mg}$ of the synthesized magnetic material was weighed into a falcon tube and washed two times with $2 \mathrm{~mL}$ of ultrapure water. Then, $2 \mathrm{~mL}$ pH 7 buffer solution was added on the particles. Then, $20 \mathrm{~mL}$ sample solution including pesticides was added to the tubes and the volume of tubes was completed until $50 \mathrm{~mL}$ with ultrapure water. For adsorption of target molecules on magnetic particles surface, the tubes were placed on an orbital shaker at $80 \mathrm{rpm}$ for $30 \mathrm{~min}$. At the end of this period, the magnetic solid phase was easily separated by using a Neodymium magnet. After separation of aquatic phase, $400 \mu \mathrm{L}$ isopropanol (2-propanol) was added to the tubes and they vortexed for $40 \mathrm{~s}$ in order to facilitate passing of pesticides molecules to organic phase. Then, the samples were filtered through a $0.45 \mu \mathrm{m}$ syringe type filter and submitted to HPLC micro vials. After every use, the magnetic particle was washed with $1 \mathrm{~mL}$ isopropanol and $1 \mathrm{~mL}$ ethanol two times. The solid phase was ready for re-use after drying at the end of this procedure.

\subsection{Preparation of Environmental Water Samples}

The accuracy and applicability of the proposed method were tested with recovery tests by using various environmental water samples. Samples were prepared by using the methods in literature [37,38]. Briefly, natural samples from river, lake, and pond collected in Sivas, Turkey (Kızılırmak River, Tödürge Lake and 4 Eylül pond) were selected for analysis. After collection, the samples were immediately transported to the laboratory and stored in the dark. Prior to the analysis, water samples were filtered through a $0.45-\mu \mathrm{m}$ PTFE filter and were stored at $4{ }^{\circ} \mathrm{C}$. All samples were analyzed in triplicate using 
the developed MSPE procedure and HPLC-PDA system. Water samples were also used in this study to calculate the recovery of pesticides at two concentration levels (100 and $300 \mathrm{ng} \mathrm{mL}^{-1}$ ).

\section{Conclusions}

Novel magnetic particles with surface grafted decanoic acid were fabricated by the chemical bonding method and were employed as a new magnetic solid phase sorbent for propoxur and fenitrothion pesticides in environmental water samples. The developed decanoic acid modified magnetic particles could provide rapid separation of propoxur and fenitrothion from the complex environmental water samples with high selectivity and demonstrated high extraction efficiency for test targets in a short-time thanks to the large surface area. The proposed approach based on MSPE-HPLC-PDA displayed satisfactory performance and could be used as a good alternative to reported analytical methodologies for trace determination of PRO and FEN in real environmental water samples.

Supplementary Materials: The following are available online, Figure S1: Absorption spectrum of PRO and FEN obtained from DAD detector.

Author Contributions: For research articles with several authors, a short paragraph specifying their individual contributions must be provided. The following statements should be used "conceptualization, A.G.C. and H.İ.U.; methodology, B.S. and H.İ.U.; software, A.K.; validation, A.G.C., B.S., H.I.U.; formal analysis, E.Y.; writing —original draft preparation, H.İ.U. and M.L.; writing—review and editing, H.İ.U. and E.Y.; visualization, A.K.; project administration, H.İ.U.; funding acquisition, H.İ.U.", please turn to the CRediT taxonomy for the term explanation. Authorship must be limited to those who have contributed substantially to the work reported.

Funding: The present study was performed with partial contributions obtained from other projects (ECZ-048, ECZ-051, ECZ-052) supported by Sivas Cumhuriyet University Scientific Research Projects Commission.

Conflicts of Interest: The authors declare no conflict of interest.

\section{References}

1. Narenderan, S.T.; Meyyanathan, S.N. Sample Treatment and Determination of Pesticide Residues in Potato Matrices: A Review. Potato Res. 2019, 62, 47-67. [CrossRef]

2. Sidhu, G.K.; Singh, S.; Kumar, V.; Dhanjal, D.S.; Datta, S.; Singh, J. Toxicity, monitoring and biodegradation of organophosphate pesticides: A review. Crit. Rev. Environ. Sci. Technol. 2019, 49, 1135-1187. [CrossRef]

3. Koc, F.; Yigit, Y.; Das, Y.K.; Gurel, Y.; Yarali, C. Determination of aldicarb, propoxur, carbofuran, carbaryl and methiocarb residues in honey by HPLC with post-column derivatization and fluorescence detection after elution from a florisil column. J. Food Drug Anal. 2008, 16, 39-45.

4. Yildiz, Y.; Jan, A.; Yildiz, Y. Determination of 2-Isopropoxyphenyl Methyl Carbamate-Propoxur in Roach Control Peanut Butter by High Performance Liquid Chromatography. J. Environ. Anal. Chem. 2017, 4, 1000199.

5. Suma, R.; Sarin, R.K.; Saiprakash, P.K.; Ramakrishna, S. Simple liquid chromatographic method for the rapid and simultaneous determination of propoxur and its major metabolite isopropoxy phenol in rat blood and urine using solid-phase extraction. J. Anal. Toxicol. 2005, 29, 728-733. [CrossRef]

6. Bazmandegan-Shamili, A.; Dadfarnia, S.; Haji Shabani, A.M.; Rohani Moghadam, M.; Saeidi, M. MultiSimplex optimization of the dispersive solid-phase microextraction and determination of fenitrothion by magnetic molecularly imprinted polymer and high-performance liquid chromatography. J. Iran. Chem. Soc. 2018, 15, 1181-1189. [CrossRef]

7. Larki, A. A novel application of carbon dots for colorimetric determination of fenitrothion insecticide based on the microextraction method. Spectrochim. Acta-Part A Mol. Biomol. Spectrosc. 2017, 173, 1-5. [CrossRef]

8. Heidari, H.; Razmi, H. Multi-response optimization of magnetic solid phase extraction based on carbon coated $\mathrm{Fe} 3 \mathrm{O} 4$ nanoparticles using desirability function approach for the determination of the organophosphorus pesticides in aquatic samples by HPLC-UV. Talanta 2012, 99, 3-21. [CrossRef]

9. Council Directive, Council of the European Union. On the quality of water intended for human consumption; Official Journal of the European Communities: Brussels, Belgium, 1998. 
10. Stoytcheva, M.; Zlatev, R.; Montero, G.; Velkova, Z.; Gochev, V. A nanotechnological approach to biosensors sensitivity improvement: Application to organophosphorus pesticides determination. Biotechnol. Biotechnol. Equip. 2018, 32, 213-220. [CrossRef]

11. Boeris, V.; Arancibia, J.A.; Olivieri, A.C. Determination of five pesticides in juice, fruit and vegetable samples by means of liquid chromatography combined with multivariate curve resolution. Anal. Chim. Acta 2014, 814, 23-30. [CrossRef]

12. Tuzimski, T.; Rejczak, T. Determination of pesticides in sunflower seeds by high-performance liquid chromatography coupled with a diode array detector. J. AOAC Int. 2014, 97, 1012-1020. [CrossRef] [PubMed]

13. Malhat, F.; Boulangé, J.; Abdelraheem, E.; Abd Allah, O.; Abd El-Hamid, R.; Abd El-Salam, S. Validation of QuEChERS based method for determination of fenitrothion residues in tomatoes by gas chromatography-flame photometric detector: Decline pattern and risk assessment. Food Chem. 2017, 229, 814-819. [CrossRef] [PubMed]

14. Maddah, B.; Javadi, S.S.; Mirzaei, A.; Rahimi-Nasrabadi, M. Application of electrospun polystyrene nanofibers as solid phase extraction sorbent for the preconcentration of diazinon and fenitrothion in environmental waters. J. Liq. Chromatogr. Relat. Technol. 2015, 38, 208-214. [CrossRef]

15. Ulusoy, H.I.; Gürkan, R.; Demir, Ö.; Ulusoy, S. Micelle-Mediated Extraction and Flame Atomic Absorption Spectrometric Method for Determination of Trace Cobalt Ions in Beverage Samples. Food Anal. Methods 2012, 5, 454-463. [CrossRef]

16. Jiang, Q.; Liu, Q.; Chen, Q.; Zhao, W.; Xiang, G.; He, L.; Jiang, X.; Zhang, S. Dicationic polymeric ionic-liquid-based magnetic material as an adsorbent for the magnetic solid-phase extraction of organophosphate pesticides and polycyclic aromatic hydrocarbons. J. Sep. Sci. 2016, 39, 3221-3229. [CrossRef]

17. Yilmaz, E.; Alothman, Z.A.; Sumayli, H.M.T.; Ibrahim, M.; Soylak, M. Sorbent extraction of Pb(II), Cu(II), $\mathrm{Ni}(\mathrm{II})$, and Fe(III) Ions as 2-(5-Bromo-2-Pyridylazo)-5-diethylamino-phenol chelates on single-walled carbon nanotube disks prior to their flame atomic absorption spectrometric determinations in animal feeds and natura. J. AOAC Int. 2012, 95, 1205-1210. [CrossRef]

18. Campone, L.; Piccinelli, A.L.; Celano, R.; Pagano, I.; Russo, M.; Rastrelli, L. Rapid and automated on-line solid phase extraction HPLC-MS/MS with peak focusing for the determination of ochratoxin A in wine samples. Food Chem. 2018, 244, 128-135. [CrossRef]

19. Liu, X.; Wang, C.; Wu, Q.; Wang, Z. Magnetic porous carbon-based solid-phase extraction of carbamates prior to HPLC analysis. Microchim. Acta 2016, 183, 415-421. [CrossRef]

20. Kabir, A.; Locatelli, M.; Ulusoy, H.İ. Recent Trends in Microextraction Techniques Employed in Analytical and Bioanalytical Sample Preparation. Separations 2017, 4, 36. [CrossRef]

21. Ulusoy, H.İ. Applications of Magnetic Nanoparticles for the Selective Extraction of Trace Species from a Complex Matrix, 1st ed.; Locatelli, M., Celia, C., Eds.; Nova Scientific Publishers: New York, NY, USA, 2017.

22. Ulusoy, H.İ.; Yılmaz, E.; Soylak, M. Magnetic solid phase extraction of trace paracetamol and caffeine in synthetic urine and wastewater samples by a using core shell hybrid material consisting of graphene oxide/multiwalled carbon nanotube/Fe3O4/SiO2. Microchem. J. 2019, 145, 843-851. [CrossRef]

23. Kudr, J.; Haddad, Y.; Richtera, L.; Heger, Z.; Cernak, M.; Adam, V.; Zitka, O. Magnetic Nanoparticles: From Design and Synthesis to Real World Applications. Nanomaterials 2017, 7, 243. [CrossRef] [PubMed]

24. Ozcan, S.; Tor, A.; Aydin, M.E. Application of magnetic nanoparticles to residue analysis of organochlorine pesticides in water samples by GC/MS. J. AOAC Int. 2012, 95, 1343-1349. [CrossRef] [PubMed]

25. Yilmaz, E.; Alosmanov, R.M.; Soylak, M. Magnetic solid phase extraction of lead(II) and cadmium(II) on a magnetic phosphorus-containing polymer (M-PhCP) for their microsampling flame atomic absorption spectrometric determinations. RSC Adv. 2015, 5, 33801-33808. [CrossRef]

26. Yilmaz, E.; Soylak, M. Preparation and characterization of magnetic carboxylated nanodiamonds for vortex-assisted magnetic solid-phase extraction of ziram in food and water samples. Talanta 2016, 158, 152-158. [CrossRef]

27. Kılınç, E.; Çelik, K.S.; Bilgetekin, H. $\gamma$-Fe2O3magnetic nanoparticle functionalized with carboxylated multi walled carbon nanotube for magnetic solid phase extractions and determinations of Sudan dyes and Para Red in food samples. Food Chem. 2018, 242, 533-537. [CrossRef] [PubMed] 
28. Barreto, I.S.; Andrade, S.I.E.; Cunha, F.A.S.; Lima, M.B.; Araujo, M.C.U.; Almeida, L.F. A robotic magnetic nanoparticle solid phase extraction system coupled to flow-batch analyzer and GFAAS for determination of trace cadmium in edible oils without external pretreatment. Talanta 2018, 178, 384-391. [CrossRef] [PubMed]

29. Singh, V.D.; Daharwal, S.J. Development and validation of multivariate calibration methods for simultaneous estimation of Paracetamol, Enalapril maleate and hydrochlorothiazide in pharmaceutical dosage form. Spectrochim. Acta Part A Mol. Biomol. Spectrosc. 2017, 171, 369-375. [CrossRef] [PubMed]

30. European Medicines Agency. ICH Topic Q2 (R1) Validation of Analytical Procedures: Text and Methodology. Available online: https://www.ema.europa.eu/en/documents/scientific-guideline/ich-q-2-r1-validationanalytical-procedures-text-methodology-step-5_en.pdf (accessed on 17 December 2019).

31. Soo Lim, H.; Young Hwang, J.; Choi, E.A.; Lee, G.; Sun Yoon, S.; Kim, M.K. Development and validation of HPLC method for the determination of ferrocyanide ion in food grade salts. Food Chem. 2018, 239, 1167-1174. [CrossRef] [PubMed]

32. Harshit, D.; Charmy, K.; Nrupesh, P. Organophosphorus pesticides determination by novel HPLC and spectrophotometric method. Food Chem. 2017, 230, 448-453. [CrossRef]

33. Yilmaz, E.; Ulusoy, H.İ.; Demir, Ö.; Soylak, M. A new magnetic nanodiamond/graphene oxide hybrid (Fe3O4@ND@GO) material for pre-concentration and sensitive determination of sildenafil in alleged herbal aphrodisiacs by HPLC-DAD system. J. Chromatogr. B Anal. Technol. Biomed. Life Sci. 2018, 1084, 113-121. [CrossRef]

34. Li, Q.; Lam, M.H.W.; Wu, R.S.S.; Jiang, B. Rapid magnetic-mediated solid-phase extraction and pre-concentration of selected endocrine disrupting chemicals in natural waters by poly(divinylbenzene-co-methacrylic acid) coated Fe3O4 core-shell magnetite microspheres for their liquid chromatography-ta. J. Chromatogr. A 2010, 1217, 1219-1226. [CrossRef] [PubMed]

35. Maddah, B.; Shamsi, J. Extraction and preconcentration of trace amounts of diazinon and fenitrothion from environmental water by magnetite octadecylsilane nanoparticles. J. Chromatogr. A 2012, 1256, 40-45. [CrossRef] [PubMed]

36. Li, M.; Jiao, C.; Yang, X.; Wang, C.; Wu, Q.; Wang, Z. Solid phase extraction of carbamate pesticides with banana peel derived hierarchical porous carbon prior to high performance liquid chromatography. Anal. Methods 2017, 9, 593-599. [CrossRef]

37. Khodadoust, S.; Talebianpoor, M.S.; Ghaedi, M. Application of an optimized dispersive nanomaterial ultrasound-assisted microextraction method for preconcentration of carbofuran and propoxur and their determination by high-performance liquid chromatography with UV detection. J. Sep. Sci. 2014, 37, 3117-3124. [CrossRef] [PubMed]

38. Tankiewicz, M.; Biziuk, M. Fast, sensitive and reliable multi-residue method for routine determination of 34 pesticides from various chemical groups in water samples by using dispersive liquid-liquid microextraction coupled with gas chromatography-mass spectrometry. Anal. Bioanal. Chem. 2018, 410, 1533-1550. [CrossRef]

Sample Availability: Samples of the compounds are available from the authors.

(C) 2019 by the authors. Licensee MDPI, Basel, Switzerland. This article is an open access article distributed under the terms and conditions of the Creative Commons Attribution (CC BY) license (http://creativecommons.org/licenses/by/4.0/). 